\title{
Follicular fluid composition in the grey seal (Halichoerus grypus) during the oestrous cycle
}

\author{
F. J. Schweigert ${ }^{1,2 *}$ and D. Schams ${ }^{1}$ \\ ${ }^{1}$ Institute of Physiology, Technische Universität München, Vöttingerstrasse 45, \\ D-8050 Freising-Weihenstephan, Germany; and ${ }^{2}$ Institute of Physiology, Physiological Chemistry and \\ Nutrition Physiology, Veterinary Faculty, Ludwig-Maximilians-Universität München, \\ Veterinärstrasse 13, D-8000 München 22, Germany
}

\begin{abstract}
During the period of lactational oestrus, the corpus luteum of ovaries of grey seals decreased in size following the birth of the pup, while on the contralateral ovary one major large follicle rapidly expanded. These large follicles had the highest concentration of oestradiol $\left(4282 \pm 609 \mathrm{ng} \mathrm{ml}^{-1}\right)$ and progesterone $\left(499 \pm 168 \mathrm{ng} \mathrm{ml}^{-1}\right)$. Osmolality (322 \pm 3 mosmol $\mathrm{kg}^{-1}$ ) and the intrafollicular concentration of electrolytes (Na: $126 \pm 1 ; \overline{C l}: 96 \pm 1$; Ca: $\left.1.3 \pm 0.1 \mu \mathrm{mol} \mathrm{ml}^{-1}\right)$ and proteins $\left(94 \pm 1 \mathrm{mg} \mathrm{ml}^{-1}\right)$ were independent of stage of lactation and follicle size. Concentrations were lower in follicular fluid than in plasma. The concentrations of triglycerides and, to some extent, those of vitamin E, cholesterol and phospholipids were affected by the decrease in the plasma concentration of these components with the onset of lactation and the increase in follicle size. These two events resulted in a marked decrease of these components in the largest follicles at the end of lactational oestrus. Vitamin A (exclusively as retinol), although a blood-borne component in follicular fluid, was the only component with a higher concentration in small and medium follicles than in plasma and decreased with increasing follicle size despite an increase in plasma retinol. This decrease and the negative correlation with intrafollicular oestradiol might indicate a high demand of preovulatory follicle structures for vitamin A owing to its possible importance in steroid hormone or protein synthesis or in both processes. Changes in the chemical composition of follicular fluid and the morphological findings indicate a continuous development of the dominant follicle throughout the lactational oestrus in grey seals.
\end{abstract}

\section{Introduction}

Information on the reproductive biology of pinnipeds in general and the oestrous cycle in particular is available through behavioural studies (Anderson and Harwood, 1985), the morphology of the reproductive tract (Craig, 1964; Boshier, 1977; Boyd, 1984; Ouellette and Ronald, 1985) and through studies on steroids in peripheral plasma (Daniel, 1975; Reaside and Ronald, 1981; Boyd, 1983; Temte, 1985; Reijnders, 1990) or in the placenta (Hobson and Boyd, 1984). No information is available concerning the composition of follicular fluid of marine mammals.

Land-breeding grey seals (Halichoerus grypus) of the northwest Atlantic give birth to their pups, each year in January and February, in areas along the coast of Nova Scotia or on remote islands such as Sable Island (Mansfield and Beck, 1977). During this time, males and females stay in the breeding colonies; they do not feed at all. There is only one oestrous cycle each year and this starts with parturition. During the short and intense period of lactation (16-18 days), a dominant follicle develops (Boyd, 1983). Oestrus and mating take place at the end of lactation. After fertilization, the implantation of the blastocyst

*Present address: Veterinär-Physiologisches Institut, Universität Leipzig, Semmelweisstrasse 2, D-7010 Leipzig, Germany.

Received 3 February 1992. occurs in pinnipeds three month later, shortly after the moult (Daniel, 1981; Boyd, 1991).

The onset of lactation in grey seals is characterized by a dramatic change in lipid metabolism owing to lipid mobilization and production of a milk extremely rich in lipids (up to 60\%). Milk production results in a considerable fall in concentration of most of the lipid components of plasma (Schweigert, in press). As lipids in follicular fluid are blood-borne, changes in their intrafollicular concentration, as well as morphological observations on follicle size, might offer an insight into the mechanism responsible for their transfer from blood into follicular fluid as well as insight into follicular development. In addition, the behaviour of vitamin $A$ in follicular fluid is of interest, owing to its possible importance in follicular development (Schweigert and Zucker, 1988) and to the fertility problems in seals associated with organochloride pollution which are thought to be linked to reduced vitamin $A$ and thyroid hormone concentrations in plasma (Brouwer et al., 1989).

\section{Materials and Methods}

Animals and collection of samples

Four pregnant and 21 lactating grey seals at different stages of lactation were sampled on Sable Island, $160 \mathrm{~km}$ east of Nova 
Scotia, Canada $\left(43^{\circ} 55^{\prime} \mathrm{N} ; 60^{\circ} 00^{\prime} \mathrm{W}\right)$ in late January and early February 1987 for this and other studies in cooperation with the Marine Fish Division of the Bedford Institute of Oceanography (Dartmouth, Nova Scotia, Canada). All females had a single fetus or pup. Seals were shot with a high-powered rifle. Blood was collected immediately after death from the jugular blood vessels. Blood serum was obtained within $2-5 \mathrm{~h}$ by centrifugation $(2750 \mathrm{~g}, 5 \mathrm{~min})$. Ovaries were removed, wrapped in aluminium foil and stored frozen at $-20^{\circ} \mathrm{C}$ within $15 \mathrm{~min}$ after death. All samples were transported on dry ice to Germany where the ovaries were thawed, their weight was recorded and the diameters (mean of two perpendicular measurements) of all follicles protruding from the surface of the ovary and of the corpus luteum were measured using sliding callipers. Follicles were divided into three categories: small $(<6 \mathrm{~mm})$, medium (6$10 \mathrm{~mm}$ ) and large follicles (>10 mm). Follicular fluid of all large follicles was sampled individually by aspiration with a syringe, while fluid from the small- and medium-sized follicles was pooled for each ovary. The follicular fluid was then frozen $\left(-40^{\circ} \mathrm{C}\right)$ again and stored until further analysis. The effects of freezing were assessed by comparing follicular fluid (seven samples from two seals at stage II of lactation) from fresh ovaries with samples from previously frozen ones with regard to steroids, lipids, fat-soluble vitamins and electrolytes. No differences were found with the exception of potassium concentration which was increased greatly in the follicular fluid of the frozen ovaries owing to cellular damage. This parameter was therefore excluded from the data.

Females were grouped into pregnant animals or into one of the three stages of lactation (pregnant, $n=4$; stage I, $n=8$; stage II, $n=6$; stage III, $n=6$ ). The estimated stage of lactation was based on the developmental stage of the pup. Like several other seal species, grey seal pups pass through several identifiable stages during the lactation period, involving changes in pelage and body fat (Boyd and Campbell, 1971). Each stage represents approximately 5 days of development (Radford et al., 1978) adding up to 16-18 days for the whole period of lactation (Boness and James, 1979). Pregnant animals were sampled $2-3$ days before parturition.

\section{Vitamin assays}

For the determination of vitamins $A$ and $E$, plasma or follicular fluid $(200 \mu \mathrm{l})$ were deproteinized with twice the volume of ethanol and vortexed. Vitamin $A$ and vitamin $E$ were extracted twice into three volumes of $n$-hexane. The organic extracts were removed and dried under a stream of nitrogen. The residue was redissolved in $200 \mu \mathrm{l}$ of methanol:ethanol $(80: 20$ $v: v)$. Finally, a $50 \mu \mathrm{l}$ sample was injected onto the column of the high-performance liquid chromatography system (HPLC). Analysis was performed as described previously (Schweigert, 1990) using a Model M6000 solvent delivery system (Waters Assoc., Milford, MA), a Model MSI T-660 autoinjector (Kontron, Eching), a Model 440 UV/VIS absorbance detector (Waters) and a Model F1000 fluorescence spectrophotometer (Hitachi Ltd, Japan). An RP-18, $4.6 \mathrm{~mm} \times 120 \mathrm{~mm}, 5 \mu \mathrm{m}$ column, preceded by a guard column packed with the same material was used. The column was eluted with methanol at a flow-rate of $1 \mathrm{ml} \mathrm{min} \mathrm{m}^{-1}(850$ p.s.i.) at room temperature.
Vitamin A was detected by measuring UV absorption at $313 \mathrm{~nm}$. The fluorometric intensity of vitamin $\mathrm{E}$ was measured (excitation $295 \mathrm{~nm}$, emission $330 \mathrm{~nm}$ ). Measurement was carried out using the external standard method by integrating peak areas with a recorder (Chromopac C-R5A, Shimadzu). All solvents used were HPLC-grade (Merck, Germany). The mean extraction recoveries were higher than $96 \%$ for both vitamins. The lower detection limit for retinol was estimated at $2 \mathrm{ng} \mathrm{ml}^{-1}$ and $1 \mathrm{ng} \mathrm{ml}^{-1}$ for $\alpha$-tocopherol. The coefficients of variation were 1.8 and $3.6 \%$ for retinol and $\alpha$-tocopherol, respectively.

\section{Hormone assays}

Concentrations of progesterone were measured in duplicate by radioimmunoassay as described by Hoffmann et al. (1973). The antiserum was raised in rabbits against $11 \alpha$-hydroxyprogesterone-hemisuccinate-BSA in our laboratory. Crossreactivity with oestrone, oestradiol, androstendione, cortisol and corticosterone was below $0.1 \%$. Sensitivity of the assay was $0.02 \mathrm{ng} \mathrm{ml}^{-1}$. Progesterone concentrations in follicular fluid were determined directly without extraction with petroleum ether. The mean intra- and interassay coefficients of variation were $7.3 \pm 0.7$ and $11.4 \pm 0.6 \%$, respectively.

Oestradiol was determined by radioimmunoassay using a modification of the method reported by Moseley et al. (1979). The rabbit antiserum (BSA-6-keto-oestradiol-6-carboxymethyloxime; raised in our laboratory) used was highly specific. Sensitivity of the assay was $1.6 \mathrm{pg}$ per tube. Oestradiol in follicular fluid was determined directly without extraction with methylene chloride. The mean intra- and interassay coefficients of variation were $8.5 \pm 1.2$ and $13.3 \pm 1.0 \%$, respectively.

Both assays were validated for serum and follicular fluid by parallelism of dilution curves and standard hormone as well as recovery studies by adding known amounts of hormone. The intra-assay coefficient of variation was derived from estimates for pooled serum samples run at least twice in duplicate in every assay covering the whole standard curve.

\section{Lipids, electrolytes and protein}

Cholesterol, phospholipids, triglycerides (Boehringer Mannheim, Germany) and free fatty acids (Wako, Neuss, Germany) were measured enzymatically using commercial test kits. Total protein was determined according to Lowry et al. (1951) using BSA as a standard. Electrolytes were estimated by a flame emission photometer, and osmolality by freezing point depression on an osmometer.

\section{Statistical analysis}

Data are presented as means \pm SEM. Comparison between the three sizes of follicle and plasma were carried out by ANOVA and the significance of difference between means was determined by the least-significant difference. Student's $t$ test was used for the comparison between the two groups (pregnant and stage I versus stage II and stage III) and between plasma and follicular fluid. 
Table 1. The mean number of follicles classified according to size, in the ovaries of pregnant and lactating grey seals

\begin{tabular}{|c|c|c|c|c|c|c|}
\hline & \multicolumn{6}{|c|}{ Size of follicle } \\
\hline & \multicolumn{2}{|c|}{ Small (<6 mm) } & \multicolumn{2}{|c|}{ Medium $(6-10 \mathrm{~mm})$} & \multicolumn{2}{|c|}{ Large $(>10 \mathrm{~mm})$} \\
\hline & Without CL & With CL & Without CL & With CL & Without CL & With CL \\
\hline Pregnant $(n=4)$ & $11.3 \pm 1.5$ & $4.8 \pm 2.0$ & $0.5 \pm 0.5$ & $1.8 \pm 1.8$ & $0.5 \pm 0.3$ & 0 \\
\hline \multicolumn{7}{|l|}{ Stage of lactation } \\
\hline Stage I $(n=8)$ & $10.6 \pm 2.3$ & $3.0 \pm 0.9$ & $3.3 \pm 2.0$ & 0 & $0.8 \pm 0.3$ & 0 \\
\hline Stage II $(n=6)$ & $8.7 \pm 2.2$ & $4.5 \pm 1.5$ & $0.5 \pm 0.2$ & $0.2 \pm 0.2$ & $1.5 \pm 0.3$ & 0 \\
\hline Stage III $(n=6)$ & $10.7 \pm 1.7$ & $4.0 \pm 2.4$ & $0.3 \pm 0.2$ & 0 & $1.5 \pm 0.2$ & 0 \\
\hline
\end{tabular}

Values are means \pm SEM.

$\mathrm{CL}=$ corpus luteum; $n=$ number of pairs of ovaries.

Table 2. Electrolytes, osmolality and total proteins in blood plasma and follicular fluid of female grey seals

\begin{tabular}{lccccc}
\hline & $\begin{array}{c}\text { Sodium } \\
\left(\mu \mathrm{mol} \mathrm{ml^{-1 } )}\right. \\
24 / \mathbf{4 7}^{\mathrm{a}}\end{array}$ & $\begin{array}{c}\text { Chloride } \\
\left(\mu \mathrm{mol} \mathrm{ml} \mathrm{m}^{-1}\right) \\
24 / 45\end{array}$ & $\begin{array}{c}\text { Calcium } \\
\left(\mu \mathrm{mol} \mathrm{ml} \mathbf{m}^{-1}\right) \\
24 / 29\end{array}$ & $\begin{array}{c}\text { Osmolality } \\
\left(\mathrm{mosmol} \mathrm{kg}^{-1}\right) \\
24 / 23\end{array}$ & $\begin{array}{c}\text { Protein } \\
\left(\mathrm{mg} \mathrm{ml}^{-1}\right) \\
24 / 29\end{array}$ \\
\hline Blood plasma & $148 \pm 0.7$ & $105 \pm 0.6$ & $2.2 \pm 0.04$ & $321 \pm 3$ & $97 \pm 1$ \\
Follicular fluid & $126 \pm 0.9^{* * *}$ & $96 \pm 0.7^{* * *}$ & $1.3 \pm 0.03^{* * *}$ & $322 \pm 3$ & $94 \pm 1^{*}$ \\
\hline
\end{tabular}

Values are means \pm SEM.

Follicular fluid values are significantly different from blood plasma values at ${ }^{*} P<0.05,{ }^{* * *} P<0.001$ (Student's $t$ test).

a $V$ alues represent the number of plasma or follicular fluid samples, respectively.

\section{Results}

\section{Morphology}

In each of the pregnant females, pregnancy had occurred in the uterus horn ipsilateral to the ovary with the corpus luteum. There was a significant decrease in the diameter of the corpus luteum from $27 \pm 2 \mathrm{~mm}$ in pregnant animals to $13 \pm 1 \mathrm{~mm}$ (mean \pm SEM) in animals at the end of lactational oestrus (stage III). Parallel to this, the weight of the ovaries with a corpus luteum continuously decreased from $17.5 \pm 2.4 \mathrm{~g}$ (mean $\pm \mathrm{SEM}$ ) to $10.1 \pm 0.4 \mathrm{~g}$ while that of the contralateral ovaries increased from $11.3 \pm 1.3$ to $14.4 \pm 1.2 \mathrm{~g}$. Only small and medium sized follicles were found on ovaries with a corpus luteum (Table 1). At least one large follicle developed per animal on the ovary contralateral to the corpus luteum from stage II of lactation onwards. In one female that appeared and behaved pregnant (fat, no pup and ready to leave the beach) an involuted uterus and a recently ovulated follicle were found but no corpus luteum. Data from this animal were excluded from analysis.

\section{Composition of follicular fluid and plasma}

The concentrations of total protein and electrolytes in plasma, and plasma osmolarity remained unchanged $(P>0.05)$ during the whole period of lactation and these data were therefore combined into one group (Table 2). Similarly, neither stage of lactation nor follicular size had an effect on the intrafollicular concentration $(P>0.05)$ of electrolytes or total proteins, or on osmolarity, and, therefore, these results were also pooled (Table 2). However, the concentrations of electrolytes $(P<0.001)$ and total proteins $(P<0.05)$ were significantly lower in follicular fluid than in plasma; no differences were observed for osmolarity.

Concentrations of oestradiol in plasma fell after parturition, increasing slightly at stages II and III of lactation, whereas progesterone concentrations decreased and remained low throughout lactation (Fig. 1). The oestrogen concentration in large follicles from animals at stage II $\left(4390 \pm 820 \mathrm{ng} \mathrm{ml}^{-1}\right)$ and stage III $\left(4174 \pm 984 \mathrm{ng} \mathrm{ml}^{-1}\right)$ of lactation was significantly $(P<0.001)$ greater than that in pregnant $\left(442 \mathrm{ng} \mathrm{ml}^{-1}\right)$ and stage $\mathrm{I}\left(1317 \pm 741 \mathrm{ng} \mathrm{ml}^{-1}\right)$ animals. This is in agreement with the increased plasma concentration of oestrogen in animals at stages II and III of lactation. Data were, therefore, summarized as (a) pregnant and stage I animals (Table 3) and (b) stage II and III animals (Table 4). The ratio of oestradiol to progesterone was $>1$ for all follicles investigated irrespective of size.

With the onset of lactation, there was a dramatic reduction $(20-65 \%)$ in the concentration of all lipids in plasma. However, this decrease was only significant for triglycerides $(P<0.01)$ and phospholipids $(P<0.001)$. Concentrations of free fatty 

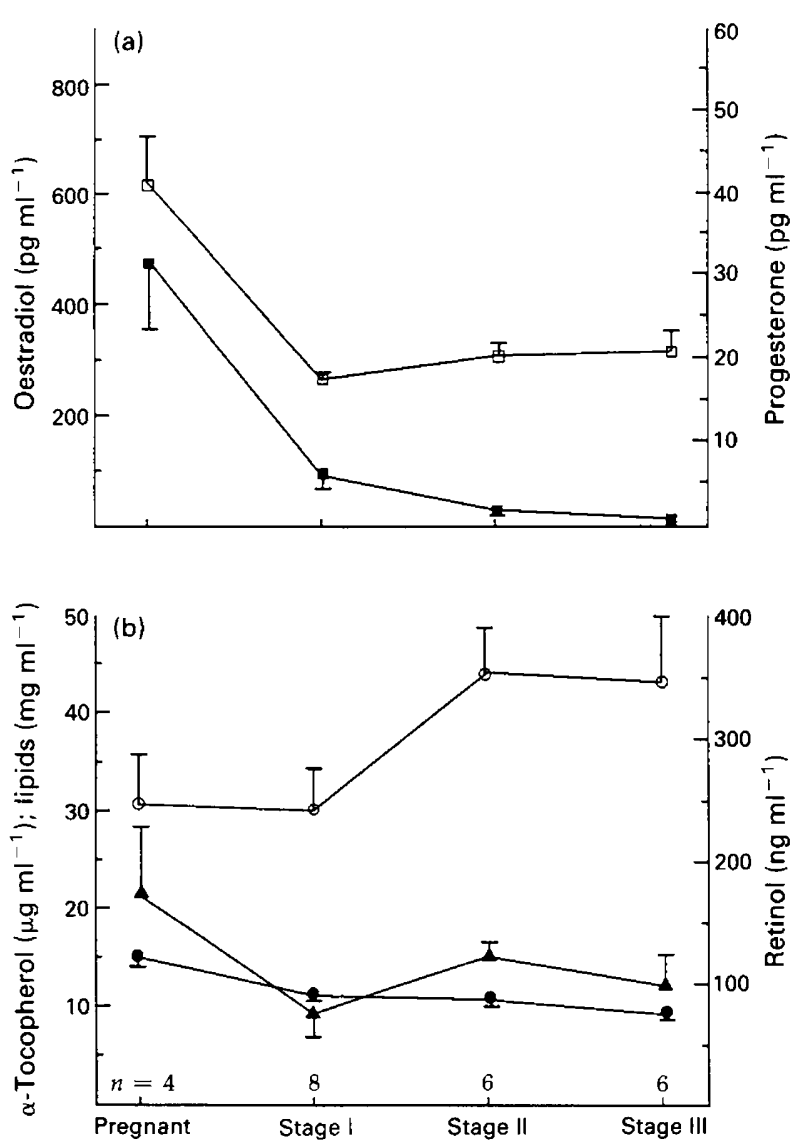

Fig. 1. Changes in the plasma concentration of (a) oestradiol ( $\square$ ) and progesterone $(\boldsymbol{\square})$, (b) lipids $(\mathbf{O})$, vitamin $A(O)$ and vitamin $E(\boldsymbol{\Delta})$ in pregnant and lactating grey seals. Each point represents the mean $( \pm \mathrm{SEM})$ of the indicated number of females.

acids and vitamin $\mathrm{A}$ increased $(P<0.001)$. The concentrations of $\alpha$-tocopherol and cholesterol in the follicular fluid from pregnant and stage I animals and from stage II and III animals were lower than those in plasma $(P<0.05)$. The intrafollicular concentrations were independent of follicle size, representing about $60 \%$ ( $\alpha$-tocopherol) and $40 \%$ (cholesterol) of plasma concentrations. At the early stage of lactation concentrations of phospholipids in follicular fluid were lower than in plasma $(P<0.05)$. This difference was not seen during the late stages (II + III) of lactation. Free fatty acids were significantly higher in follicular fluid than in plasma $(P<0.05)$ with only minor differences among the different size categories.

In pregnant and early lactating females, the concentrations of retinol in follicular fluid corresponded to that found in plasma. Later (stages II and III) the concentration of retinol in small follicles was significantly higher than in plasma and the other follicle size categories $(P<0.05)$ in which the concentration was even lower than in plasma $(P<0.05)$. No vitamin $A$ esters could be detected in either plasma or follicular fluid. In all samples of follicular fluid investigated, concentrations of triglycerides were higher than those of plasma $(P<0.05)$. Although plasma concentration of triglycerides fell sharply at parturition $(p<0.001)$ without any further changes throughout the lactation period, the concentration in the follicular fluid of small follicles remained at a constant value throughout the cycle (Table 5). With increasing follicular size, there was a significant decrease in triglycerides in follicular fluid at all stages $(P<0.05)$. There were significant negative correlations $(P<0.001 ; n=65-82)$ between oestradiol and retinol $(r=$ $-0.26), \alpha$-tocopherol $(r=-0.16)$, triglycerides $(r=-0.39)$ or cholesterol $(r=-0.17)$.

\section{Discussion}

Morphometric data on corpus luteum regression and changes in the weight of the ovaries as well as findings on size distribution of follicles during the oestrous cycle correspond to the related literature (Boyd, 1983, 1984; Hobson and Boyd, 1984).

Oestradiol and progesterone concentrations in plasma of seals show similar changes to those reported for terrestrial mammals with regard to parturition and ovulation. The decrease in oestradiol concentration, observed after parturition here, is in agreement with that found by Raeside and Ronald (1981) and the tendency to increase again at the end of the oestrous cycle agrees with the work of Boyd (1983) and Reijnders (1990). The sharp fall in concentration of plasma lipids (with the exception of retinol and free fatty acids) with the onset of lactation is obviously caused by the rapid and massive energy transfer into a milk very rich in lipids (up to $60 \%$ ) (Schweigert, 1993).

Steroids are the products of granulosa or theca cell metabolism and their intrafollicular concentrations reflect the functional stage of the follicles. Consequently the highest steroid concentrations are associated with large, non-atretic follicles (Ireland and Roche, 1983). In grey seals, at least one oestrogen-rich follicle per animal was found from stage II of lactation onwards. This follicle may be responsible for the concomitant increase of plasma oestrogen similar to that seen in other species (Bomsel-Helmreich et al., 1979; Hillier, 1981). The concentrations of oestrogen and to some extent progesterone in follicular fluid were higher than those in terrestrial mammals (Eiler and Nalbandov, 1977; Henderson et al., 1982). This might be the reason for the high concentrations of steroids found in the plasma of marine mammals (Sawyer-Steffan et al., 1983).

All components in follicular fluid known to be transferred from blood into follicular fluid are closely correlated with their concentrations in plasma (for review, see McNatty, 1978), but their relative concentration is negatively correlated with their molecular weight (Andersen et al., 1976). Consequently, in grey seals, blood components of a low molecular weight such as electrolytes, osmolality and total proteins were in the range of those of plasma and thus comparable to those found in other species (Shalgi et al., 1972; David et al., 1973; Andersen et al., 1976; Wise, 1987). Lipids, except retinol and free fatty acids, are transported in the blood bound to lipoproteins. The larger classes of lipoprotein of very-low and low density are excluded from follicular fluid owing to their molecular mass $(>850 \mathrm{kDa})$ and the transfer of high density lipoproteins is limited to about $50 \%$ of plasma concentration (Andersen et al., 1976). Thus, the intrafollicular concentration of lipids is lower than that in plasma (Chang et al., 1976; Perret et al., 1985). This was found to be the case in grey seals for $\alpha$-tocopherol, cholesterol and phospholipids. There is, however, much variation in the distribution of lipids among the lipoprotein classes in 
Table 3. Changes in the concentration of steroids, lipids and fat-soluble vitamins in blood plasma and follicular fluid of pregnant and early lactating (stage I) grey seals

\begin{tabular}{|c|c|c|c|c|}
\hline \multirow[b]{2}{*}{$n$} & \multirow[b]{2}{*}{$\begin{array}{c}\text { Plasma } \\
12\end{array}$} & \multicolumn{3}{|c|}{ Follicular fluid } \\
\hline & & $\begin{array}{c}\text { Small }^{*} \\
21\end{array}$ & $\begin{array}{l}\text { Medium* } \\
23\end{array}$ & $\begin{array}{l}\text { Large }^{*} \\
6\end{array}$ \\
\hline Oestradiol (ng ml ${ }^{-1}$ ) & $0.393 \pm 0.063^{\mathrm{a}}$ & $470 \pm 106^{b}$ & $757 \underset{(16)}{ \pm} 197^{b}$ & $1026 \pm 512^{b}$ \\
\hline Progesterone (ng ml$l^{-1}$ ) & $15.5 \pm 5.1^{\mathrm{a}}$ & $\begin{array}{c}58 \pm 7^{\mathrm{a}} \\
(20)\end{array}$ & $91 \pm 15^{\mathrm{a}}$ & $133 \pm 18^{a}$ \\
\hline Retinol (ng ml ${ }^{-1}$ ) & $250 \pm 19^{a}$ & $261 \pm 28^{a}$ & $182 \pm 14^{\mathrm{b}}$ & $291 \pm 56^{\mathrm{a}}$ \\
\hline$\alpha$-Tocopherol $\left(\mu \mathrm{g} \mathrm{ml}^{-1}\right)$ & $16.4 \pm 3.26^{\mathrm{a}}$ & $8.9 \pm 0.60^{\mathrm{b}}$ & $9.9 \pm 0.80^{b}$ & $11.7 \pm 1.60^{b}$ \\
\hline Cholesterol (mg ml $\left.{ }^{-1}\right)$ & $3.2 \pm 0.21^{\mathrm{a}}$ & $1.3 \pm 0.06^{b}$ & $1.1 \pm 0.05^{c}$ & $1.5 \pm 0.15^{b}$ \\
\hline Phospholipids ( $\mathrm{mg} \mathrm{ml}^{-1}$ ) & $5.9 \pm 0.22^{a}$ & $4.7 \pm 0.13^{b}$ & $4.4 \underset{(15)}{ \pm 0.16^{b}}$ & $3.8 \pm 0.43^{c}$ \\
\hline Triglycerides (mg ml ${ }^{-1}$ ) & $1.8 \pm 0.34^{\mathrm{a}}$ & $2.9 \pm 0.19^{b}$ & $2.1 \pm 0.10^{c}$ & $1.9 \pm 0.10^{c}$ \\
\hline Free fatty acids $\left(\mu \mathrm{mol} \mathrm{ml}{ }^{-1}\right)$ & $1.7 \pm 0.17^{\mathrm{a}}$ & $4.5 \pm \frac{ \pm 0.22^{b}}{(20)}$ & $3.4 \pm 0.28^{c}$ & $3.5 \pm 0.71^{\mathrm{c}}$ \\
\hline
\end{tabular}

Values are means \pm SEM.

Values in brackets represent the number of samples measured.

Values with different superscripts are significantly different at $P<0.05$.

*Follicle size.

Table 4. Changes in the concentration of steroids, lipids and fat-soluble vitamins in blood plasma and follicular fluid of grey seals during the later part of lactation (stage II and III)

\begin{tabular}{|c|c|c|c|c|}
\hline \multirow[b]{2}{*}{$n$} & \multirow[b]{2}{*}{$\begin{array}{c}\text { Plasma } \\
12\end{array}$} & \multicolumn{3}{|c|}{ Follicular fluid } \\
\hline & & $\begin{array}{l}\text { Small }^{*} \\
18\end{array}$ & $\underset{6}{\text { Medium }}$ & $\begin{array}{l}\text { Large }^{*} \\
\quad 18\end{array}$ \\
\hline Oestradiol (ng ml $\left.{ }^{-1}\right)$ & $0.335 \pm 0.025^{a}$ & $340 \pm 196^{b}$ & $507 \underset{(5)}{ \pm} 232^{b}$ & $4282 \pm 609^{c}$ \\
\hline Progesterone (ng ml-1) & $1.4 \pm 0.2^{\mathrm{a}}$ & $44 \pm 5^{\mathrm{a}}$ & $48 \pm 7^{\mathrm{a}}$ & $499 \pm 168^{b}$ \\
\hline Retinol (ng ml ${ }^{-1}$ ) & $349 \pm 32^{\mathrm{a}}$ & $527 \pm 53^{\mathrm{b}}$ & $227 \pm 37^{c}$ & $211 \pm 16^{\mathrm{c}}$ \\
\hline$\alpha$-Tocopherol $\left(\mu \mathrm{g} \mathrm{ml}^{-1}\right)$ & $13.6 \pm 1.70^{\mathrm{a}}$ & $7.8 \pm 0.31^{\mathrm{b}}$ & $6.4 \pm 0.52^{\mathrm{b}}$ & $7.5 \pm 0.43^{b}$ \\
\hline Cholesterol $\left(\mathrm{mg} \mathrm{ml}^{-1}\right)$ & $2.9 \pm 0.15^{a}$ & $1.7 \underset{(16)}{ \pm 0.08^{b}}$ & $1.4 \pm 0.10^{c}$ & $1.2 \pm 0.07^{\mathrm{c}}$ \\
\hline Phospholipids ( $\mathrm{mg} \mathrm{ml}^{-1}$ ) & $4.8 \pm 0.18^{\mathrm{ab}}$ & $\begin{array}{c}5.0 \pm 0.15^{a} \\
(14)\end{array}$ & $4.6 \pm 0.20^{\mathrm{ab}}$ & $4.5 \pm 0.11^{\mathrm{b}}$ \\
\hline Triglycerides $\left(\mathrm{mg} \mathrm{ml}^{-1}\right)$ & $0.8 \pm 0.06^{a}$ & $2.9 \pm 0.18^{b}$ & $2.3 \underset{(5)}{ \pm} 0.13^{c}$ & $1.9 \pm 0.14^{c}$ \\
\hline Free fatty acids $\left(\mu \mathrm{mol} \mathrm{ml}^{-1}\right)$ & $2.3 \pm 0.16^{\mathrm{a}}$ & $4.2 \pm 0.20^{b}$ & $4.1 \pm 0.28^{b}$ & $4.2 \pm 0.23^{b}$ \\
\hline
\end{tabular}

Values are means \pm SEM.

Values in brackets represent the number of samples measured.

Values with different superscripts are significantly different at $P<0.05$.

*Follicle size.

terrestrial and marine mammals (Chapman, 1980). These differences may be responsible for the distinct differences observed among the different lipids in follicular fluid. Higher concentrations of free fatty acids in follicular fluid than those in plasma have also been reported for pigs (Yao et al., 1980). Their carrier protein in blood, however, is the much smaller albumin (molecular mass $66 \mathrm{kDa}$ ) which can pass the blood-follicular barrier freely (Andersen et al., 1976). 
Table 5. Changes in the concentration of triglycerides $\left(\mathrm{mg} \mathrm{ml}^{-1}\right)$ in blood plasma and follicular fluid of pregnant and lactating grey seals

\begin{tabular}{|c|c|c|c|c|}
\hline & \multirow[b]{2}{*}{ Plasma } & \multicolumn{3}{|c|}{ Follicular fluid } \\
\hline & & Small $^{*}$ & Medium* & Large $^{*}$ \\
\hline $\begin{array}{c}\text { Pregnant } \\
(n)\end{array}$ & $3.0 \pm 0.38^{\mathrm{a}}$ & $2.7 \pm 0.27^{\mathrm{a}}$ & $1.8 \pm 1.7^{b}$ & $\begin{array}{c}1.4 / 1.9 \\
(2)\end{array}$ \\
\hline \multicolumn{5}{|c|}{ Stage of lactation } \\
\hline $\begin{array}{l}\text { Stage I } \\
(n)\end{array}$ & $1.1 \pm 0.15^{a}$ & $3.0 \pm 0.26^{b}$ & $2.1 \pm 0.12^{c}$ & $2.0 \pm 0.09^{c}$ \\
\hline $\begin{array}{c}\text { Stage II } \\
(n)\end{array}$ & $0.9 \pm 0.09^{a}$ & $2.7 \pm 0.24^{b}$ & $2.2 \pm 0.17^{b}$ & $1.6 \pm 0.09^{b c}$ \\
\hline $\begin{array}{l}\text { Stage III } \\
(n)\end{array}$ & $0.7 \pm 0.06^{a}$ & $3.1 \pm 0.28^{b}$ & $\begin{array}{c}2.4 / 2.6 \\
(2)\end{array}$ & $2.1 \pm 0.23^{c}$ \\
\hline
\end{tabular}

Values are means \pm SEM.

Values in brackets represent the number of samples measured for each stage.

Values with different superscripts are significantly different at $P<0.05$.

*Follicle size.

The concentration of retinol in small follicles of grey seals was higher than that in plasma and decreased as follicle size increased during the later stages of lactation. This is contrary to the findings of Schweigert and Zucker (1988) in cattle. Vitamin $\mathrm{A}$ is a blood-borne component bound to a carrier complex of a molecular weight that would allow free passage across the blood-follicular fluid barrier. Thus, an increasing concentration of vitamin A with increasing follicle size would be expected, because the concentration of retinol in plasma rose significantly during the later stages of lactation and thus newly formed follicular fluid should have originated from plasma with higher concentrations of retinol. This observed discrepancy points to the selective, rather than passive, transfer of retinol into follicular fluid. In other tissues, specific receptors tightly control the vitamin A uptake of the cells (Blomhoff et al., 1990). This control of vitamin A uptake should be of particular importance for follicular structures where rapid cell differentiation and steroid production might be very sensitive to the harmful effects of excess or deficiency of vitamin A. The decrease of retinol with follicular growth together with the negative correlation between oestrogen and retinol may indicate a high requirement of vitamin $A$ in cell differentiation and enzyme or steroid synthesis or both (Roberts and Sporn, 1984). Furthermore, it is possible that fertility problems associated with organochloride pollution in marine mammals (Reijnders, 1986) are due to the potential effects of polychlorinated biphenyls (PCBs) on lowering blood concentrations of vitamin $\mathrm{A}$ as observed in rats (Brouwer and van den Berg, 1984; Brouwer et al., 1989). The lower concentrations of retinol in blood might result in an insufficient transfer of vitamin A to follicular structures where it is of importance owing to its function in differentiation as well as enzyme and steroid synthesis.

In contrast to that of other lipids, the concentration of triglycerides was always higher in the follicular fluid from lactating seals than in their plasma. There was a sharp decrease in the plasma concentration of these substances from $3 \mathrm{mg} \mathrm{ml}^{-1}$ to concentrations below $1 \mathrm{mg} \mathrm{ml}^{-1}$ with the onset of lactation.
Intrafollicular concentrations of triglycerides were lower than plasma concentrations before parturition but did not follow the decrease in the plasma concentration. With follicular growth, however, the concentration in follicular fluid decreased owing to dilution with the lower concentration of triglycerides in plasma. Since this is opposite to the behaviour observed for retinol, it further supports our hypothesis of an actively controlled transfer of retinol from blood into follicular fluid.

The changes in the chemical composition of follicular fluid, together with the morphological findings of this study and those of Boyd (1983), may give us an idea of the dynamics of follicular development in grey seals during the oestrous cycle. The rather constant number of small follicles, the decrease in the number of medium-sized follicles and the concomitant increase of the number of large follicles may indicate that the largest follicle per pair of ovaries has continuously developed during the oestrous cycle. This is further supported by a constant high concentration of triglycerides and phospholipids in small follicles which shows that no new follicles are produced during the oestrous cycle. Thus, follicular development in the grey seal seems to occur in only one wave during the 16-18 days of lactational oestrus.

The assistance of the author's colleagues at the Marine Fish Division of the Bedford Institute of Oceanography in the collection of samples is kindly acknowledged, especially B. Beck and W. T. Stobo. The study was supported in part by the Hanns-Seidel-Stiftung München e.V., Germany and the Deutsche Forschungsgemeinschaft (DFG: Sch 373/1-1).

\section{References}

Andersen MM, Krell J, Byskov AG and Faber M (1976) Protein composition in the fluid of individual bovine follicles Journal of Reproduction and Fertility 48 109-118

Anderson SS and Harwood J (1985) Time budgets and topography: how energy reserves and terrain determine the breeding behaviour of grey seals Animal Behaviour 33 1343-1348 
Blomhoff R, Green MH, Berg T and Norum KR (1990) Transport and storage of vitamin A Science 250 399-404

Bomsel-Helmreich O, Gougeon A, Thebault A, Saltarelli D, Milgrom E, Frydman R and Papiernik E (1979) Healthy and atretic human follicles in the preovulatory phase: differences in evolution of follicular morphology and steroid content of follicular Aluid Joumal of Clinical Endocrinology and Metabolism 48 686-694

Boness DL and James H (1979) Reproductive behaviour of the grey seal (Halichoerus grypus) on Sable Island, Nova Scotia Joumal of Zoology, London 188 477-500

Boshier DP (1977) Observations on the corpus luteum of the grey seal (Halichoerus grypus, Nilsson, 1820) at the time of ovaimplantation. In Functional Anatomy of Marine Mammals pp 333-359 Ed. RJ Harrison. Academic Press NY

Boyd IL (1983) Luteal regression, follicle growth and the concentration of some plasma steroids during lactation in grey seals (Halichoerus grypus) Journal of Reproduction and Fertility 69 157-164

Boyd IL (1984) Development and regression of the corpus luteum in the grey seal (Halichoerus grypus) ovaries and its use in determining fertility rates Canadian Journal of Zoology 62 1095-1100

Boyd IL (1991) Environmental and physiological factors controlling the reproductive cycles of pinnipeds Canadian Journal of Zoology 69 1135-1148

Boyd JM and Campbell RN (1971) The grey seal (Halichoerus grypus) at North Rona, 1959-1968 Joumal of Zoology, London 164 469-512

Brouwer A and van den Berg KJ (1984) Early and differential decrease in natural retinoid levels in $\mathrm{C} 57 \mathrm{BL} / \mathrm{Rij}$ and DBA/2 mice by $3,4,3^{\prime}, 4^{\prime}$-tetrachlorobiphenyl Toxicology of Applied Pharmacology 73 204-209

Brouwer A, Reijnders PJH and Koeman JH (1989) Polychlorinated biphenyl (PCB)-contaminated fish induces vitamin A and thyroid hormone deficiency in the common seal (Phoca vitulina) Aquatic Toxicology 15 99-106

Chang SCS, Jones JD, Ellefson RD and Ryan RJ (1976) The porcine ovarian follicle. I. Selected chemical analysis of follicular fluid at different developmental stages Biology of Reproduction 15 321-328

Chapman MJ (1980) Animal lipoproteins: chemistry, structure, and comparative aspects Journal of Lipid Research 21 789-853

Craig AM (1964) Histology of reproduction and the estrus cycle in the female fur seal, Callorhinus ursinus Journal of Fish Research Board of Canada 21 773-811

Daniel JC Jr (1975) Concentrations of circulating progesterone during early pregnancy in the northern fur seal, Callorhinus ursinus Journal of Fish Research Board of Canada 32 65-66

Daniel JC Jr (1981) Delayed implantation in the northern fur seal (Callorhinus ursinus) and other pinnipeds Journal of Reproduction and Fertility Supplement 29 $35-50$

David A, Frenkel G, Kraicer PF and Weinstein A (1973) Chemical composition of rabbit follicular fluid Fertility and Sterility 24 227-229

Eiler H and Nalbandov AV (1977) Sex steroids in follicular fluid and blood plasma during the oestrous cycle of pigs Endocrinology $100331-338$

Henderson KM, McNeilly AS and Swanston IA (1982) Gonadotrophin and steroid concentrations in bovine follicular fluid and their relationship to follicle size Joumal of Reproduction and Fertility 65 467-473

Hillier SG (1981) Regulation of follicular oestrogen biosynthesis: a survey of current concepts Journal of Endocrinology $893 \mathrm{P}-18 \mathrm{P}$

Hobson BM and Boyd IL (1984) Gonadotrophin and progesterone concentrations in placentae of grey seals (Halichoerus grypus) Journal of Reproduction and Fertility 72 521-528

Hoffmann B, Kyrein HJ and Ender ML (1973) An efficient procedure for the determination of progesterone by radioimmunoassay applied to bovine peripheral plasma Hormone Research 4 302-310
Ireland JJ and Roche JF (1983) Growth and differentiation of large antral follicles after spontaneous luteolysis in heifers: changes in concentration of hormones in follicular fluid and specific binding of gonadotropins to follicles Journal of Animal Science 57 157-167

Lowry OH, Rosebrough NJ, Farr AL and Randall RJ (1951) Protein measurement with the Folin phenol reagent Journal of Biological Chemistry 193 265-275

McNatty KP (1978) Follicular fluid. In The Vertebrate Ovary pp 215-259 Ed. RE Jones. Plenum Press, NY

Mansfield AW and Beck B (1977) The grey seal in eastern Canada Fisheries and Marine Service Technical Report 704 1-51

Moseley WM, Forrest DW, Kaltenbach CC and Dunn TG (1979) Effect of norgestomet on peripheral levels of progesterone and estradiol-17 $\beta$ in beef cows Theriogenology 11 331-341

Ouellette J and Ronald K (1985) Histology of reproduction in harp and grey seals during pregnancy, postparturition, and estrus Canadian Journal of Zoology 63 1778-1796

Perret B-P, Parinaud J, Ribbes H, Moatti J-P, Pontonnier G, Chap H and DousteBlazy L (1985) Lipoprotein and phospholipid distribution in human follicular fluids Fertility and Sterility $\mathbf{4 3}$ 405-409

Radford PJ, Summers CF and Young KM (1978) A statistical procedure for estimating grey seal pup production from a single census Mammal Review 8 $35-42$

Raeside JI and Ronald K (1981) Plasma concentrations of oestrone, progesterone and corticosteroids during late pregnancy and after parturition in the harbour seal, Phoca vitulina Journal of Reproduction and Fertility 61 135-139

Reijnders PJH (1986) Reproductive failure in common seals feeding on fish from poliuted coastal waters Nature 324 456-457

Reijnders PJH (1990) Progesterone and oestradiol-17 $\beta$ concentration profiles throughout the reproductive cycle in harbour seals (Phoca vitulina) Journal of Reproduction and Fertility $90403-409$

Roberts AB and Sporn MB (1984) Cellular biology and biochemistry of the retinoids. In The Retinoids Vol. II pp 209-289 Eds MB Sporn, AB Roberts and DS Goodman. Academic Press, Orlando/NY

Sawyer-Steffan JE, Kirby VL and Gilmartin WG (1983) Progesterone and estrogens in the pregnant and nonpregnant dolphin, Tursiops truncatus, and the effects of induced ovulation Biology of Reproduction 28 897-901

Schweigert FJ (1990) Effect of gestation and lactation on lipoprotein pattern and composition in dairy cows Journal of Animal Physiology and Animal Nutrition $6375-83$

Schweigert FJ Effects of energy mobilization during fasting and lactation on plasma metabolites in the grey seal (Halichoerus grypus) Comparative Biochemistry and Physiology A (in press)

Schweigert FJ and Zucker $H$ (1988) Concentrations of vitamin $A, \beta$-carotene and vitamin $\mathrm{E}$ in individual bovine follicles of different quality journal of Reproduction and Fertility 82 575-579

Shalgi R, Kraicer PF and Soferman N (1972) Gases and electrolytes of human follicular fluid Journal of Reproduction and Fertility 28 335-340

Temte JL (1985) Photoperiod and delayed implantation in the northem fur seal (Callorhinus ursinus) Journal of Reproduction and Fertility 73 127-131

Wise T (1987) Biochemical analysis of bovine follicular fluid: albumin, total protein, lysosomal enzymes, ions, steroids and ascorbic acid content in relation to follicular size, rank, atresia, classification and day of oestrous cycle Joumal of Animal Science 64 1153-1169

Yao JK, Ryan RJ and Dyck PJ (1980) The porcine ovarian follicle. VI. Comparison of fatty acid composition of serum and follicular fluid at different developmental stages Biology of Reproduction 22 141-147 